See discussions, stats, and author profiles for this publication at: https://www.researchgate.net/publication/347250268

\title{
SUPPORT SYSTEMS, ENTREPRENEURSHIP EDUCATION AND THE CHALLENGES OF START-UPS IN DEVELOPING ECONOMIES
}

Conference Paper · November 2020

DOI: $10.21125 /$ iceri.2020.2127

CITATIONS

4 authors, including:

Q Mary Ejiehi Ezema

Covenant University Ota Ogun State, Nigeria

4 PUBLICATIONS O CITATIONS

SEE PROFILE

Felicia Omowunmi Olokoyo

Covenant University Ota, Nigeria

78 PUBLICATIONS 666 CITATIONS

SEE PROFILE
READS

95

Omotayo Adegbuyi

Covenant University Ota Ogun State, Nigeria

34 PUBLICATIONS 97 CITATIONS

SEE PROFILE

Some of the authors of this publication are also working on these related projects:

The Effects of Entreprenuerial Activities on Youths' Empowerment: case study of selected faith-based View project

ASSESSING THE PERFORMANCE NEEDS OF HEADS OF ACADEMIC DEPARTMENTS OF NIGERIAN UNIVERSITIES View project 


\title{
SUPPORT SYSTEMS, ENTREPRENEURSHIP EDUCATION AND THE CHALLENGES OF START-UPS IN DEVELOPING ECONOMIES
}

\author{
M. Ezema, O. Adegbuyi, F. Olokoyo, C. Moses \\ Covenant University Ota (NIGERIA)
}

\begin{abstract}
Entrepreneurship has been recognised as an essential strategy for economic growth. It is also known for solving unemployment problems and reducing the poverty level. Entrepreneurship education is aimed at providing knowledge, skills, competencies, and motivation to create and innovate important business ideas that can lead to start-ups or businesses in various settings. Economic development, as witnessed by developed countries, can be traced to entrepreneurial activities. There are various motivating factors for starting a business. One of such motivating factors is the availability of support systems. Such supports include entrepreneurship education, enabling environmental/policies, infrastructure, media/market information, and finance. The effects of these support systems in developing economies such as Nigeria need to be properly examined to understand why many startups fail to develop into thriving and prosperous businesses. This paper intends to identify and discuss the challenges of start-ups and why support systems are important in developing economies. The methodology adopted for the study is a literature review. The study found that the absence or inadequate entrepreneurial support systems play a vital role in the attrition rate of start-ups within the study context.
\end{abstract}

Keywords: Developing economies, entrepreneurship education, start-ups, support system.

\section{INTRODUCTION}

Globally, there is a push to fast-track the development and growth of nations through start-ups and SMEs. For some time now, the advanced and emerging nations are determined to invigorate start-ups through strong government support policies, mainly because start-ups are becoming the driving dynamism of employment generation and growth engines. It has become a priority to support new business as global agenda because start-ups play a crucial role in driving growth and improving development. It is essential to recognise an important strategy that will influence launching new and pertinent companies, which will project, grow and sustain products/services that meet the desires of the people and are appropriate for developing the economy. Around the world, start-ups are playing a vital role in the development of economies. In addition to building entrepreneurs, start-ups are also developing innovative and enhanced business ideals and products [1].

In the same vein, job openings are being generated enormously by promising start-ups. In developing countries, a massive number of start-ups have sprung up in the past few years; a substantial part of them have closed down within the first year. Evidence has shown that in developing countries, the success rate of start-ups has been very low and discouraging [2], which aligns with the submission that about $90 \%$ of start-ups in the world [3] and $61 \% \%$ of start-ups in Nigeria [4] fail as quickly as they are created. It has also been observed that many failed start-ups occurred within 18 months after their creation. The consequence of start-up failure is a business collapse, which ultimately compounds the unemployment problem [5]. Several reasons have been adduced as to why start-ups fail of which are lack of a support system, effective entrepreneurship education, and these tend to be very challenging in developing nations, including Nigeria. Hence the need to nurture entrepreneurs through entrepreneurship education, mentoring, coaching, consulting, and all other support facilities necessary for developing an enterprise to function optimally and provide maximum effect. Precisely, this paper addresses the following research questions:

1 What are the challenges of entrepreneurship education in supporting start-ups in developing economies?

2 What are the challenges of other support systems in supporting start-ups in developing economies?

3 In what way can entrepreneurship education and other support systems sustain start-ups in developing economies? 
Developing entrepreneurship is broadly seen as a serious agenda to generate job opportunities, improve livelihood, and develop the economy. Entrepreneurship includes identifying a business prospect, organising resources, and stick to exploit that prospect [6]. In the same vein, [7] defined entrepreneurship as the recognition of gaps and business prospects within your surroundings and conveying together the needed resources in a new way to fill these gaps, bearing the hazards involved and, in the course achieving rewards. The focus here is on successful entrepreneurial activity, which involves the formation, identification, and exploitation of optimistic openings in such a way that embroils the improvement of products/processes. Schumpeter has regarded entrepreneurship as a creative activity meaning that Innovation is an explicit device of entrepreneurship. Peter F. Drucker (1934), a supporter of the concept of entrepreneurship, has considered it as the adaptation of several innovations in businesses, new production techniques, new products, new markets, new marketing methods, new qualities of raw materials, new packaging and new combination on methods are used. Mcclelland is among the important Scholars that view entrepreneurship as a high achievement ability perception and that deciding risk and innovation capacities are necessary. He stated that the ability to accomplish work with a modern approach and deciding uncertainties is the hallmark of entrepreneurship. In developing countries, including Nigeria, it has more or less been used as a synonym for business management for decades, while entrepreneurship education has a more recent history.

Entrepreneurship education (EE) generally studies the why, when, and how of opportunity generation, identification, and exploitation of providing products/services through the formation of new firms (start-ups) and within existing firms for both profit and non-profit drives. Entrepreneurship education includes all activities targeting to nurture business attitudes, approaches, expertise, and covering a collection of traits such as idea generation, start-up, development, and invention [8]. Since in section, an effort has been concentrated on what entrepreneurship education is and why it is necessary, particularly in developing countries. How effective are entrepreneurship education in transforming knowledge and skill into start-ups and their challenges? It is high time to shift from the traditional teaching of the theory of entrepreneurship to the pedagogical method. Entrepreneurship education is seen as an important element to develop entrepreneurship attitudes for future entrepreneurs.

The debate has been whether entrepreneurship can be taught or entrepreneurs are born; however, professionals and educators have progressed beyond that fable. Based on this and its importance to economic development, entrepreneurship education has been made compulsory in almost all the educational systems in the world, developing countries including. EE is recognised to play a significant role in an economic system. Researchers such as([9], [10], [11])opined entrepreneurship education as a component that accelerates economic growth, generates employment and jobs, thereby empowering the underprivileged who may not have access to job opportunities.

Entrepreneurship education has numerous features (a) is a process that provides talents to identify business prospects (b) it centres on understanding and evolving an individual ability in quest of business accomplishments, talents, and qualities in diverse backgrounds(c) it is carried out on both secondary and higher education students aside an official degree admitting programmes. The World Bank stated that higher education institutions are means through which developing countries can empower individuals with entrepreneurial abilities that can assist in driving economic growth. The objectives of EE drivers vary from increasing entrepreneurship thinking, principle, and boldness, motivating students' with the intention of creating new businesses and employment. Entrepreneurship education purposes are to develop current and prospective entrepreneurs with appropriate abilities and awareness to either generate new businesses or improve the current businesses[12].

However, studies on the importance of entrepreneurship education are abundant, but there is limited literature on the challenges faced in effectively developing such education, generally in developing countries and specifically in Nigeria [13]. Since the role and outcome of entrepreneurship on job generation and economic growth of developed countries revealed the importance, there has been growing effort to educate and teach knowledge and principle of entrepreneurship to managers, businessmen, and students. Nowadays, teaching and educating human resources is one of the unavoidable tasks of establishments and organisations[14]. An important challenge of entrepreneurship in the education of dynamic entrepreneurs that they need to learn appropriately to sustain their businesses. In particular, understanding how to do business and access to social networks are considered imperative ([15],[16]). Entrepreneurship education is aimed at providing knowledge, skills, competencies, and motivation to create and innovate important business ideas that can lead to startups or businesses in various settings. 
Start-up is a newly found business to grow into an established enterprise. It is an emerging entrepreneurial venture with a fast-growing business, growing/successively offering an innovative product, process, or service [1]. A start-up symbolises a newly emerged business venture that has the aim of growing a realistic business ideal to meet the desires of people by generating an honest sequence that pushes perpetual enhancement through innovative keys[17]. A start-up is an entrepreneurial venture which is classically a newly emerged, fast-growing business that intends to meet a marketplace requirement by providing an innovative product, process, or service. According to [18], a start-up is a temporary organisation designed to pursuit a repeatable and scalable business model. Around the world, start-ups are playing a vital role in the development of economies in a faster stride. In conclusion, [19] stated that start-ups are more appropriate for developing economies because their major aim is to alleviate poverty and create viable wealth, solving industrial issues through Innovation. Start-ups generate models planned of performance of the country based, especially on those aspects as the serious elements to energise transformation. These are still challenging in developing economies.

Developing nations/economies, on the other hand, are struggling nations that still require assistance from associates around the world [20]. World Bank [21] designed "countries with around $\$ 1,005$ per capita income as low-income countries, middle-income countries as those with a gross national income between $\$ 1,006$ and $\$ 3,955 "$. By the World Bank estimation, "both low and middle-income countries are developing countries. Similarly, the United Nations has stated that there is no agreed definition of developing countries. UN, however, recommended the following criteria, low human development indexes (HDI), country indebtedness, and the ability to tackle climate change problems, state of governance, access to, and weight in international trade. Also, developing countries have a low level of living, high population growth, underdeveloped industries, high and rising levels of unemployment and underemployment, dependence and vulnerability in international relations, and reliance on agriculture. Such countries include Nigeria, Cameroon, Kenya, Ethiopia, Rwanda, Malawi, Cambodia, Tunisia, Lebanon, Haiti, Indonesia, Malaysia, Sierra Leone, India, China, Uganda, and Russia, Bangladesh, among others. Therefore, creating a sustainable environment/support system for start-up firms is one of the major challenges the developing countries are having. Hence the need for support systems that will enable start-ups to grow into contributing to the economy.

Entrepreneurial Support System. 'Support System is a network of people who offer an individual with practical or emotional support' (Merriam-Webster Dictionary) also a group of people who give someone assistance (Learner's Dictionary). Evidence has shown the benefits of a strong support system such as higher levels of well-being, improved coping skills, and longer and healthier life. It also reduces depression, anxiety, and stress. In the same vein, start-ups are considered to be mainly at risk at the period of infancy. An entrepreneurial support system is necessary for their survival. Entrepreneurs are in high need of a strong support system to enable them to turn their start-up ideas into valuable businesses. To improve lives and the development of the economies, supporting entrepreneurs is necessary. The society needs innovations and operative results to find a solution to existing problems. Supporting entrepreneurs is supporting Innovation and development. The support usually comes from different quarters, and they can play various roles to help create the right foundations for entrepreneurs [22]

[23] examined the correlation between entrepreneurship education and entrepreneurial motivation among university students. The findings were that Entrepreneurship competencies are predictions of entrepreneurship motivation while the knowledge was found not to be a prediction. The study also found out that entrepreneurship education does not motivate university students to become entrepreneurs. The study suggested that the pedagogy approach should be emphasised in the development of student entrepreneurship skills for motivation. The findings are not to discourage us but to enable us to push for entrepreneurship education support that is aimed at developing strong, well-motivated, and successful entrepreneurs. The implication of this is that entrepreneurship education should focus more on learning-by-doing activities in a group setting and network context. Standard teaching for start-ups and commercialising institutions' research findings should be the goal. The more reason a support system should be in place for both the students and teachers. In the same vein, [24] examined the link between university support systems, knowledge sharing, and Innovation, using four Universities. The findings discovered that university support systems develop students' knowledge sharing for innovations as proof of entrepreneurial intentions. The suggestion from this study is that university support systems, which include mentoring, seed funding, business incubation, among others, are germane areas for the entrepreneurial development of students. This ends up in enhancing their competencies and operational efficiencies as potential entrepreneurs. 
The research was done by [25] on the support system and its role in entrepreneurial development in India. The researcher stated that youths could nurture and develop entrepreneurship steadily if the support system is provided for them. The findings also discovered that training support system generates a multiplier effect on prospects for job creation, capacity to manage start-ups, increase in business ownership and such develop the social base of the Indian entrepreneurial class and also increase the formation and spreading of new knowledge and understanding of the entrepreneurial concept and practice through investigation. Similarly, an exploratory study was also carried out by[26] concerning the support system provided by the government in countries like India, Saudi Arabia, United Arab Emirates, China, Uganda, and Russia. The exploratory study was based on woman entrepreneurship and its support system across developing countries. The study gives an insight into the present situations and conditions of the woman and also gives ground representativeness. The support system in the corporate business world or small owned business is important to the sustainability of their start-ups. Government support and several structures that are implemented have a lasting effect on the development of women entrepreneurship.

\section{METHODOLOGY}

This research was carried out through review of various conceptual and empirical. Google scholar search was used, focusing on keywords such as entrepreneurial support system in developing countries, entrepreneurship education in developing countries, and the challenges of entrepreneurial support system and entrepreneurship education in developing countries. In order to appropriately reflect the geographical sector, the study comprehensively researched literature and the Internet, and empirical studies on some developing countries like Sierra Leone, Nigeria, India, China, Uganda, and Russia were reviewed. The various empirical studies reviewed established the reason why entrepreneurship education and other support systems are necessary for start-ups and especially in developing countries.

\section{RESULTS}

\subsection{Challenges of entrepreneurship education in developing economies}

Major challenges emerged from the entrepreneurship education in developing countries and have also contributed to the failure of start-ups in these economies. Researchers like ([27];[28]) identified the problems with current entrepreneurship education in Nigeria as an unsuitable learning environment, lack of updated teacher's schedule, inability to understand student's interest, lack of access to modern equipment for vocational and skills among others. [12] also stated that lack of experienced entrepreneurship educators, a theory-driven approach, government policies, inadequate system to improve curricula, cultural perception, and lack of funding as challenges facing entrepreneurship education in developing countries. While [29]cited lack of data as one of the main challenges, researchers face in developing countries. There is a serious problem with the graduate youths not being taught most talents wanted by employers to gain a competitive advantage or start-up business. The setback with the theory-driven approach is that it discourages students to effectively engage with the hard realities of the business environment.

\subsection{Challenges of entrepreneurial support system to start-ups in developing economies}

Also, good macroeconomic settings and business environments include infrastructure, regulation, and legal settings that have been typically underscored to improve entrepreneurial activities and generate employment. These are particularly pressing challenges in developing countries where wage and salary employment is inadequate, and self-employment forms the mainstream of job creation. Generally, and based on the findings, which are also in line with [30]

The burden of tax is huge for new ventures, and the entrepreneurs in these economies, there is a substantial burden of personal and corporate tax, which is obstructing the investment from the corporate world. Investment in infrastructure like roads, electricity, modern technologies, plants, and equipment in these countries is very low, making entrepreneurs and their staff less productive. This is another challenge for upcoming entrepreneurs as the governments invest very less in infrastructure development. The consequence also is the chain effect reaction that will subsequently lead to rising prices-another challenge in the low investment in education and skill development centres. The effect 
is a shortage of knowledge and skill creation that will discourage the development of entrepreneurs and reduce entrepreneurial activities. Methods of teaching are also not motivated enough for nascent entrepreneurs to start businesses.

The entrepreneurs are confused because of the difficulty in solving the inflation problem. Inflation hinders the economic growth of a nation; as the interest rates are increasing, it is also pushing up the rate of exchange. Currently, they lack institutional strength and political inclination to apply needed transformations that help to sustain growth. These challenges arise in these economies that the proportion of small and medium enterprise/start-ups are lower in developing countries as compared to any other emerging/developed economies. In general, developing countries are becoming less friendly for businesses due to all these challenges.

\subsection{Effective support systems and entrepreneurship education to start-ups in developing economies}

The various support systems could be from entrepreneurship education, government, investors, mentors (entrepreneurs), the education sector, financial institutions, family, and media. The investing option is a win-win one for both the investors and the people and companies they are investing in [22]. Based on the findings, figure 1 was designed for easy articulation of the various roles of Support Systems that will change the face of start-ups in developing economies:

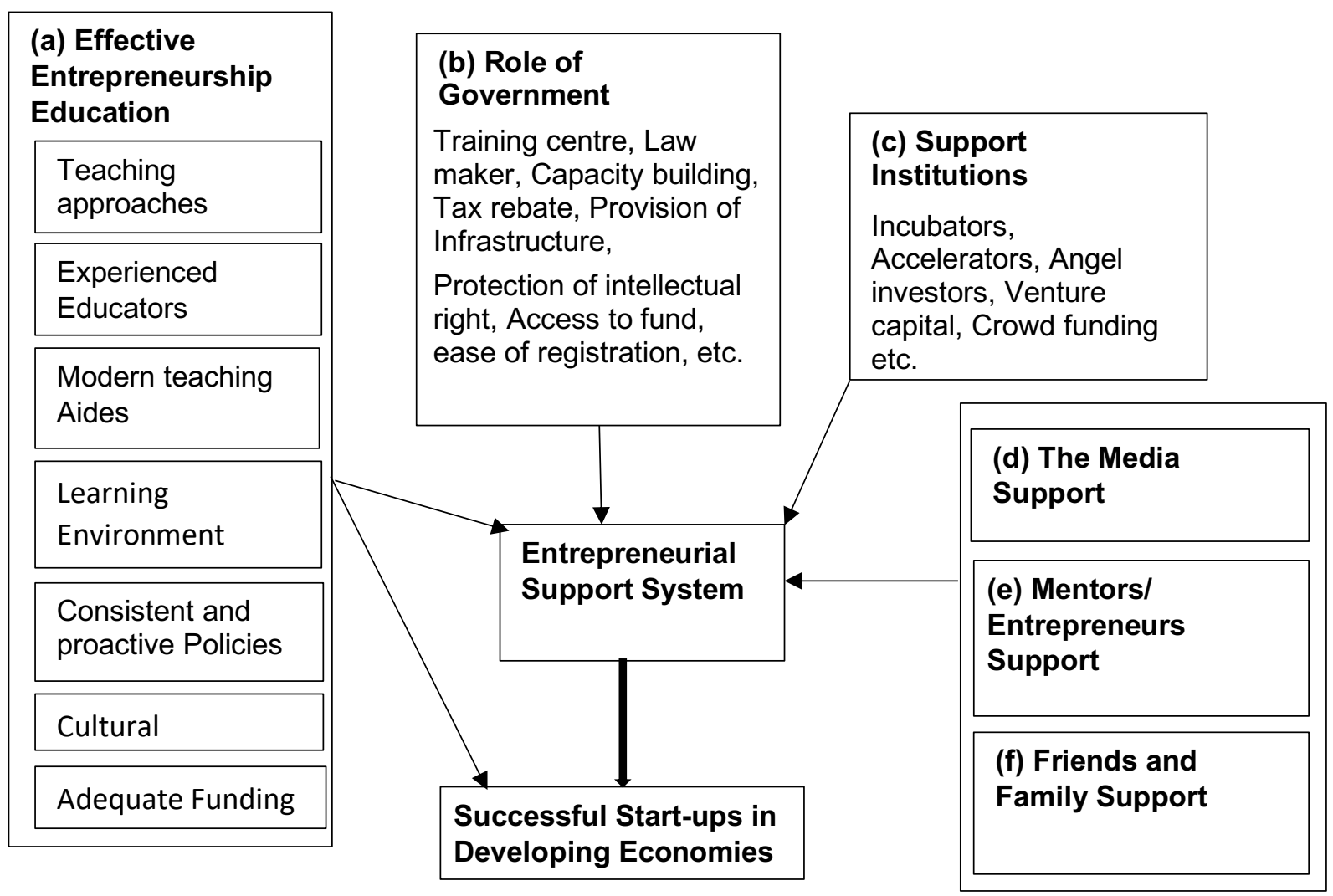

Figure 1.Support System for Successful Start-ups in Developing Economies (Schematic Model)

\section{A. Effective Entrepreneurship Education for Successful start-ups in developing economies}

Educators, teachers, and trainers enhance the leadership skills of students and also help them realise their talents. With the right approach to teaching, educational institutions can plant an entrepreneurial mindset among young students. Changes among educators, teachers, and trainers must be made to motivate the leadership skills and natural talents of their students. The provision of modern, adequate, and appropriate teaching aids should be provided. Entrepreneurship can be activated by applying the correct approaches, environment, and approaches. A pedagogical approach to entrepreneurship education should be adopted. It will also encourage an increase in academic spin-offs. Colleges and universities need to set up entrepreneurship clubs and incubators, which provide students with a 
platform to experiment and turn their ideas someday into business ventures [22]. Effective entrepreneurship education will be discussed specifically:

The right approach to teaching: [31] identified two main approaches for delivery entrepreneurship, theoretical, and practical-oriented. The first teaches entrepreneurship on a theoretical foundation while the practical oriented focus essentially on action-oriented delivery. Both approaches will complement each other if properly adopted.

Experienced Entrepreneurship Educators: Entrepreneurship educators are a vital aspect of any EE programme. Educators with qualification and background in entrepreneurship like the developed country, for instance, the USA, that has relevant knowledge, skills, and attitudes required to design, deliver and assess EE programmes. Also, effective teachers use a group of teaching approaches as there is no particular, general method that fits all conditions-different schemes with different amalgamations with different gatherings of students to develop their learning results.

Provision of modern, adequate, and appropriate teaching aids: An effective curriculum design should aim at involving all stakeholders, for example, students, trainers, businesses, and policymakers who can help shape the learning outcomes, educating, and evaluating approach of the programme. The development of entrepreneurship education has made known of what is needed to learn and practice entrepreneurship-openness to educating the students' entrepreneurial mindsets and actions with contemporary education aids.

Right learning Environment: Education environment should be conducive for appropriate learning.

Modernisation instructional tenets and classroom models to stimulate team-based, action-oriented education in areas targeted to develop teamwork and resourcefulness that embrace actual world teamwork with entrepreneurship professionals and with drive markets for new products and services.

Government Policies: The policies and programmes of countries should be consistent and proactive in reformatting the ability of the education system to offer entrepreneurial capabilities and proficiency for their citizenries.

Cultural Perception: The profession of entrepreneurship is treated as a profession for school dropouts in most country. The belief that entrepreneurship is meant for those who could meet up with admission requirement into schools, thereby making certain cultures to embrace entrepreneurship more than others. Entrepreneurship should be made a national culture.

Adequate Funding: There should be an increase in the fund for entrepreneurship education and advancement and support innovative apparatuses to influence collaborations with companies, NonGovernment Organisations, international institutions and foundations, as well as with personalities

\section{B. The Role of the Government}

The government must work towards improving the business environment, which is a prerequisite for developing entrepreneurship support systems. The government can help build the support system by introducing provisions for setting up a one-window system for business incorporation, providing tax alleviation for small businesses, and setting up start-up funds for entrepreneurs. They also need to create an investment-friendly environment for investors by devising FDI friendly policies to attract foreign investors and businesses [22]. In any country, government policies and principles are significant for effective entrepreneurship development; they make it potential for start-ups to existing without limiting their development. Governments that support entrepreneurs improve and implement growthoriented structures that allow enterprise development. The strategic importance of start-ups to the national economy is of the wide range such as an easy way of generating employment, increasing GDP, improving the standard of living, among others. Therefore the government should support entrepreneurship, encourage and support entrepreneurs who dare to start their own business. Some of the government policies that allow for growth, as stated by [32].

Intellectual Property Rights. The need to protect intellectual property is vital to stimulate innovative ideas. If innovators are not protected legally, they will not like to share ideas, and that will affect their growth. Entrepreneurs will only be willing to develop their ideas if they are sure that their ideas will be misappropriated.

Modified Entrepreneurship Education Curricula. Government policies that will indorse and incorporate a modified entrepreneurship curriculum in the educational system will create a culture of innovative, solution-orientated individuals who will grow to start their businesses and contribute to the 
economy. Though most countries have made entrepreneurship compulsory in their educational system, the system of imparting the knowledge is not motivating enough for the students.

Ease of Business Registration. Ease of business registration will help to remove barriers to starting business; entry requirement should be attainable for both formal and informal businesses. Entrepreneurship flourishes when the requirements to start a business are not unreasonable, such as operational taxes to registration processes.

Access to Funding for Start-Ups. Another major challenge that entrepreneurs face is access to capital and investment. After undergoing through entrepreneurship programmes, there is a need to provide seed funding to participants to encourage them to start a business. Governments can support in this area by encouraging local banks to work with start-ups and small businesses by providing loans or investment. Though most developing countries have designated banks for such, there is still a lot of bottle-neck for accessing such loans. When loans are given, there should be monitoring for proper application.

Incentivised Tax Laws. Tax reformation to promote start-ups and SMEs growth is very crucial. A reduction in corporate or reforming tax low will have an optimistic ripple effect on the economy by increasing the possibility of new venture start-ups. The decision-makers and lawmakers in these countries should make decisions that will advance the business environments like tax reliefs for small businesses/start-ups and entrepreneurs.

Provision of Infrastructure. Providing infrastructures in developing countries is still a major issue. Social amenities like roads, water, electricity, and hospitals help facilitate business. These facilities help to reduce the cost of running businesses and motivate starting a business. There is hardly any business you can run without the light. These are requirements to increase entrepreneurial activities. These infrastructures involve huge resources which entrepreneurs cannot afford, given this, various central and state government institutions have to come forward to help small entrepreneurs to provide them with the support and facilities.

Capability Development. Short courses on cash-flow management, how to bid and prepare tender documents, export preparation should be periodically carried on entrepreneurs. In the area of market and export, information on new markets and regulatory issues of imports and new exporters' programme should be handy. Market opportunities - updating entrepreneurs in current marketing opportunities. Intellectual Property Management Training for entrepreneurs.

Skill Acquisition Training Centres. Availability of training centres that are accessible to those who need the training. Also, making incubation centres obtainable is very vital to ease starting business.

Young Entrepreneur Competition. Organising competitions for young entrepreneurs in different categories will boost the zeal to put in more effort into success.

\section{Role of Support Institutions}

Institutional support makes the economic environment more conducive for the growth of the business.

A start-up incubator is a designed collective platform with the sole purpose to help start-ups grow and succeed. They help entrepreneurs resolve some problems commonly connected with running a startup such as providing workspace, seed funding, mentoring, and training. They are often connected with universities, and some business schools (such as Hebron start-up incubator, Columbia business schools start-up incubator, and Roar start-up incubator) allow their students and alumni to take part in these programs. Other incubators are formed by governments, civic groups, start-up organisations, or successful entrepreneurs and the focus of incubators varies by region. Incubator programs help to fill the gap through fundamental training to entrepreneurs, business space and sometimes contact investors [33].

Accelerators are more recent than incubators, early programmes were funded primarily by venture capitalists, and newer programmes are being established by a broader range of associations, both corporate and public sectors. Seed funding is a common feature of most of them, but the new players have different operations that lead to differences in selection benchmarks, funding models, and success measures. Since the business environment is uncertain, and the cost of running a business is a high couple with other challenges, working with others that will mentor and support makes a great transformation.

Angel investors are "high net-worth, non-institutional, private equity investors who have the desire and sufficiently high net worth to enable them to invest part of their assets in high risk, high-return 
entrepreneurial ventures in return for a share of voting, income and ultimately capital gain" [34]. Angel investors usually invest in early-stage ventures when the founders have drained their funds, also where the businesses are not strong to stand on their own or satisfactorily attractive to gain venture capital funding. It can also be said that an angel investor is a wealthy person who offers capital for a business start-up, usually in exchange for convertible debt or ownership equity [34]

Venture Capital. "Venture capital firms are made of professional investors, and their money comes from a variety of sources - corporations and individuals, private and public pension funds, foundations". Their job is to look for businesses with high potential growth. They buy the shares, have a say in the running of the company, in exchange for their contribution as they expect a high rate of return on investment. Years after, the venture capitalists sell their shares in the company back to the owners, thereby making much more than what they put in.

Crowdfunding is a method of contribution by the general public donations to fund start-up capital for new businesses. This concept comprises of getting a small amount from a large number of individuals/organisations to fund some new start-ups. Different types of crowdfunding include donation crowdfunding, reward crowdfunding, crowdfunded lending, and equity crowdfunding. The type of fund models has its return and stimulation for the funder.

\section{Media Support}

From promoting new enterprises and highlighting the efforts of entrepreneurs in writing about unsung business heroes, there is a lot the media can do. The success stories and inspirational journeys they feature can encourage more people to make something of them. This exposure will not only motivate the entrepreneurs of today but also encourage many more of tomorrow [35]

\section{E. The Role of Mentors/Entrepreneurs}

Mentoring helps entrepreneurs by giving them direction and improving their knowledge on how to develop their real-time skills [36] The mentorship factor is important because advice and assistance from mentors assist start-ups to increase their success opportunities ([37], [38]). Keep in mind that someone who works as a mentor is likely to have sympathy for your situation, not to mention similar past experiences to draw upon in offering advice. Another part of the appeal is those fellow entrepreneurs are likely, to be honest with you. Entrepreneurs play the most important role in developing a support system for themselves. Once they make it, they then need to inspire, motivate, and support more people to become entrepreneurs. To help strengthen the support system, they need to guide aspiring entrepreneurs in the role of angel investors [35].

\section{F. Friends and family}

Nascent entrepreneurs of the uncertainties of doing business and are ready to face them, but they are faced with an important decision. The support of family and friends is very important for entrepreneurs and start-up owners. They are already sacrificing a lot of their time which can affect their relationships with the others.

\section{CONCLUSION}

The significance of start-ups cannot be ignored by any functional and serious government of any nation, particularly in developing nations where their economies are having severe challenges. Thus, in line with the arguments of previous studies, this study proposed to adopt an entrepreneurial support system, including entrepreneurship education as a possible moderator in performance of start-ups in developing countries. If these approaches are charted passionately, the result will offer a significant development in various countries. Various opportunities are available for the entrepreneurs, but the challenges of start-ups in the developing economies need to be addressed if entrepreneurs are to achieve and sustain successful start-ups through various support systems. Creating a conducive environment for start-ups increase rapid growth and sometimes, more or less unconventional strategies are needed to stimulate more of entrepreneurial culture.

\section{ACKNOWLEDGEMENT}

The authors wish to appreciate the management of Covenant University for offering sponsorship for this research work. 


\section{REFERENCES}

[1] M. S. Shamsi and M. A. Khan, "Entrepreneurship and Start-up: A success story of ChaiCalling". Stand-up India - International Conference on Entrepreneurship and Women Empowerment 18 19 November 2016. NIESBUD Noida, India pp. 46-53. 2016

[2] A. Akinso, "Successful strategies for the survival of business owners in Nigeria," (Published Thesis). Walden University, Minneapolis, Minnesota, United State, 2018.

[3] N. Patel, "90\% Of Start-ups Fail: Here's What You Need To Know About The 10\%", 2015. Retrieved from https://www.forbes.com/sites/neilpatel/2015/01/16/90 Accessed on 03/082020.

[4] F. Egbesola, Nigeria records $61 \%$ start-ups' failure in 9years, among the top 10 African countries with high failure rates, (B. Oluwabunmi, Reporter) Lagos: Business Day, March. 18, 2020

[5] R. S. Dauda, "Poverty and economic growth in Nigeria: Issues and policies," Journal of Poverty, vol. 21, no 1, PP. 1-19, 2016.

[6] Onyebueke and Ochnongo, Entrepreneurship and economic development, Enugu: Precision Printers and Publishers, 2002.

[7] C. L. Emmanuel, Entrepreneurship: A conceptual Approach $2^{\text {nd }}$ Edition. Agege-Lagos, Pumark Nigeria Limited, Educational Publishers, 2008.

[8] A. Zahra, K. F. Mansoreh and I. Narges, "A Study of Teaching Methods in Entrepreneurship Education for Graduate Students," Higher Education Studies, vol. 2, no.1, pp. 1-9, 2012.

[9] O. H. Abimbola, \& G. M. Agboola. "Environmental factors and entrepreneurship development in Nigeria." Journal of Sustainable Development in Africa, vol.13, no. 4, pp 166-176, 2011.

[10] G. de Wit, \& J. de Kok. (2014). "Do small businesses create more jobs? New evidence for Europe". Small Business Economics, vol. 42, no.1, pp. 283-295, 2014.

[11] C. Blattman, J. Annan, E. P. Green, C. Lehmann, \& J. Jamison, "The returns to microenterprise development among the ultra-poor: A field experiment in post-war Uganda". American Economic Journal: Applied Economics, vol. 8, no. 2, pp. 35-64, 2015.

[12] A. Mbeteh, \& M. M. Pellegrini, "Entrepreneurship Education in Developing Countries: A Study of the Key Challenges in Sierra Leone". African Entrepreneurship, Palgrave Studies of Entrepreneurship in Africa, vol. 3, no.5, pp. 89-116, 2018.

[13] A. A. Agbonlahor, "Challenges of entrepreneurial education in Nigerian universities: Towards a repositioning for impact". Journal of Educational and Social Research, 6(1), 208-214. 2016.

[14] F. Vakili, N. Tahmasebi, S. Tahmasebi, \& D. Tahmasebi, "Role of Education in Entrepreneurship Development”. J. Ecophysiol. Occup. Hith. Vol.16, no. 3\&4 pp.78-87, 2016.

[15] C. P. Eveleens, F. J. Van Rijnsoever, \& E. Niesten, "How network-based incubation helps start-up performance: A systematic review against the background of management theories". The Journal of Technology Transfer, 42, 676-713, 2017.

[16] M. A. Van Weele, F. J. Van Rijnsoever, \& F. Nauta, "You Can't Always Get What You Want: How Entrepreneur's Perceived Resource Needs Affect the Incubator's Assertiveness". Technovation, 59, pp.18-33, 2017.

[17] H, Al-Mubaraki and B. Michael, "Challenges and opportunities of innovation and incubators as a tool for knowledge-based economy", Journal of Innovation and Entrepreneurship, SpringerOpen, 2017.

[18] S. Blank, "Why the Lean Start-Up Changes Everything", Harvard Business Review, 2013.

[19] F. Daso, "When It Comes To Start-ups In Developing Countries, Play The Long Game". Forbes.Com, 2018, retrieved from https://www.forbes.com/sites/frederickdaso/2018/10/10

[20] J. Reynolds, "Difference between developing countries and emerging countries," Bizfluent, 2018, available on bizfluent.com

[21] World Bank, "Country Classification". Available on datahelpdesk.worldbank.org, 2019.

[22] K. R. Joshi," Building a powerful support system for entrepreneurs", Start-ups Nepal, pp.1-8, 2016. 
[23] M. Farhangmehr, P. Goncalves, and M. Sarmento, "Predicting entrepreneurial motivation among university students: The role of entrepreneurship education", Education + Training, vol. 58, no. 7/8, pp. $861-881,2016$.

[24] M. A. Olokundun, O. Ogunnaike, F .Peter, A. S. Ibidunni and A. B. Amaihian. "Examining the link between university support systems, knowledge sharing and innovation: a focus on Nigerian university students," Journal of Entrepreneurship Education, vol. 20, no. 2, pp.1-10, 2017.

[25] A. Koch, "Support system and its role in entrepreneurial development in India," (published Thesis), Economy \& Finance, Business, Technology, pp.1-107, 2014.

[26] H. P. Bulsara, J. Chandwani, S. Ghandhi and H. Miniaoui Support system for women entrepreneurship in India, Saudi Arabia, United Arab Emirates, China, Uganda and Russia: A comparative exploratory study. Man in India, 94 (4-II): 879-913, 2014.

[27] S. A. Ojeifo, S. A. 'Entrepreneurship Education in Nigeria: A Panacea for Youth'. Journal of Education and Practice, vol.4, no. 6, 61-66, pp. 2012.

[28] M. E. Ezema, C. L. Moses, O. Adegbuyi, \& A. Omolade, "The Essentials of Pedagogical Approach to Entrepreneurship Education in Nigeria". Education Excellence and Innovation Management: A 2025 Vision to Sustain Economic Development during Global Challenges (pp. 17690 - 17699). Seville, Spain: IBIMA 2020.

[29] V. Ramadani, L. Dana, \& S. Tahiri, "The context of Islamic entrepreneurship and business: concept, principles and perspectives". International Journal of Business and Globalisation, vol.15, no.3, pp. 244-261, 2015.

[30] H. P. Bulsara, J. Chandwani, S. Ghandhi and H. Miniaoui, "Support system for women entrepreneurship in India, Saudi Arabia, United Arab Emirates, China, Uganda and Russia: A comparative exploratory study. Man in India, vol. 94, no. (4-II), pp. 879 - 913, 2014.

[31] Y. Yamakawa, K. McKone-Sweet, J. Hunt, \& D. Greenberg, "Expanding the focus of entrepreneurship education: Pedagogy for teaching the entrepreneurial method". Journal of Business and Entrepreneurship, vol. 27, no. 2, pp.19-46. 2015.

[32] S. Gunjan and K. Kushagra, "Challenges and opportunities of entrepreneurs in emerging economies," International Journal of Public Administration and Management Research (IJPAMR), vol. 2, no. 3, pp. 1 - 8. 2014.

[33] M. Mbazo, "Policies with a purpose: Government policies that support entrepreneurship in Africa Celebrating innovation," Young African Entrepreneurs, pp. 1-3, 2017.

[34] H. Van, B. C. Jonas and M. Wright, "A Look inside Accelerators," Nesta, 2015 www.nesta.org.uk/sites/default/files/a_look_inside_accelerators.pdf.

[35] A. Vekic and J. Borocki, "The role of institutions in supporting start-up companies," XVII International Scientific Conference on Industrial Systems (IS'17). Novi Sad, Serbia.486- 491, 2017.

[36] O. Jaško and S. Marinković, "Reshaping the future through sustainable business development and entrepreneurship, Symposium proceedings," XV International symposium Symorg 2016: Reshaping. pp.1462, 2016.

[37] G. P. Kumar, "Indian start-up-Issues, Challenges and Opportunities", Conference: Indian Start-up Ecosystem-Challenges and Opportunities, March 2018. Retrieved from https://www.researchgate.net/publication/323855305.

[38] D, Dellermann, N., Lipusch, P, Ebel, K. M. Popp, and, J. M. Leimeister, "Finding the Unicorn: Predicting Early Stage Start-up Success through a Hybrid Intelligence Method", in International Conference on Information Systems (ICIS). Seoul, South Korea, 2017. 